Article

\title{
Low-Carbon Composite Based on MOC, Silica Sand and Ground Porcelain Insulator Waste
}

\author{
Adam Pivák 1Dㅡ, Milena Pavlíková ${ }^{1}$ D , Martina Záleská ${ }^{1}$, Michal Lojka ${ }^{2}$, \\ Anna-Marie Lauermannová ${ }^{2} \mathbb{D}$, Ondřej Jankovský ${ }^{2}$ and Zbyšek Pavlík ${ }^{1, *}$ \\ 1 Department of Materials Engineering and Chemistry, Faculty of Civil Engineering, Czech Technical \\ University in Prague, Thákurova 7, 16629 Prague 6, Czech Republic; adam.pivak@fsv.cvut.cz (A.P.); \\ milena.pavlikova@fsv.cvut.cz (M.P.); martina.zaleska@fsv.cvut.cz (M.Z.) \\ 2 Department of Inorganic Chemistry, Faculty of Chemical Technology, University of Chemistry and \\ Technology Prague, Technická 5, 16628 Prague 6, Czech Republic; michal.lojka@vscht.cz (M.L.); \\ lauermaa@vscht.cz (A.-M.L.); ondrej.jankovsky@vscht.cz (O.J.) \\ * Correspondence: pavlikz@fsv.cvut.cz; Tel.: +42-0224-354-731
}

Received: 2 July 2020; Accepted: 10 July 2020; Published: 13 July 2020

\begin{abstract}
Magnesium oxychloride cement-based composites (MOC) with silica sand/porcelain waste blended fillers were designed and tested. The objective of the presented research was to design and test low carbon, eco-friendly and viable alternatives to Portland cement-based materials. To make new materials environmentally acceptable and sustainable, silica sand applied in the reference composite material was partially substituted by ground porcelain waste (PW) coming from used electrical insulators. The sand substitution ratio was 5, 10, and 15 vol.\%. The chemical and mineralogical composition, morphology, and particle size distribution of porcelain waste were measured. For silica sand, porcelain waste, and $\mathrm{MgO}$, specific density, loose bulk density, and Blaine fineness were determined. The effect of porcelain waste on the workability of fresh composite mixtures was characterized by spread diameter. The composites were characterized by their basic structural, mechanical, hygric, and thermal properties. The phase composition and thermal stability at high temperatures of MOC/porcelain waste pastes were also analyzed. Fourier-transform infrared spectroscopy (FT-IR) analysis helped to indicate main compounds formed within the precipitation of MOC phases and their reaction with porcelain waste. The usage of porcelain waste greatly decreased the porosity of composite matrix, which resulted in high mechanical resistance and reduced and decelerated water imbibition. The $10 \%$ sand substitution with porcelain waste brought the best mechanical resistance and the lowest water absorption due to the formation of amorphous phases, water-insoluble aluminosilicates. In case of the thermal performance of the examined composites, the low thermal conductivity of porcelain waste was the contradictory parameter to porosity and the high thermal stability of the phases present in porcelain slightly decreased the thermal decomposition of composites with porcelain waste dosage. Based on the results emerged from the experimental tests it was concluded that the partial substitution of silica sand in MOC composites enabled the development of materials possessing interesting and advanced function and technical parameters.
\end{abstract}

Keywords: magnesium oxychloride cement (MOC); silica sand substitution; porcelain insulator waste; workability; structural parameters; mechanical resistance; hygrothermal performance

\section{Introduction}

In the building industry, the tendency towards eco-friendly materials gradually grows due to the increasing rate of pollution. This trend is manifested in the continuous search for alternative materials to the widespread Portland cement (PC), mostly because of the enormous amount of released carbon 
dioxide connected with its production. The manufacturing process of production of PC is assigned with approximately $7 \%$ of the total anthropogenic emissions of $\mathrm{CO}_{2}$ [1]. The energy consumption of this procedure is also very large, mostly due to the high temperature of clinkering (approx. 15\% of industrial energy consumption) [2]. One of the possible alternatives is magnesium oxychloride cement.

Magnesium oxychloride cement (MOC) is an alternative non-hydraulic binder obtained by mixing $\mathrm{MgO}$ powder with aqueous solution of $\mathrm{MgCl}_{2}$. This has been known since 1867 , when it was invented by French engineer Stanislas Sorel [3]. The term magnesium oxychloride cement includes various compounds in the system $\mathrm{MgO}-\mathrm{MgCl}_{2}-\mathrm{H}_{2} \mathrm{O}$. The four commonly known phases are Phase 3, Phase 5, Phase 2 and Phase 9. Phase $3\left(3 \mathrm{Mg}(\mathrm{OH})_{2} \cdot \mathrm{MgCl}_{2} \cdot 8 \mathrm{H}_{2} \mathrm{O}\right)$ and Phase $5\left(5 \mathrm{Mg}(\mathrm{OH})_{2} \cdot \mathrm{MgCl}_{2} \cdot 8 \mathrm{H}_{2} \mathrm{O}\right)$ can be prepared at ambient temperature and are the two main phases responsible for the hardness of MOC. They react with the $\mathrm{CO}_{2}$ from the atmosphere while forming magnesium carbonates [4-7]. The ability to capture $\mathrm{CO}_{2}$ during carbonation in combination with the lower calcining temperature of the raw materials makes it superior to $\mathrm{PC}$ in terms of the emissions of $\mathrm{CO}_{2}$ and the negative influence on the environment. Tang et al. reported that the total carbon foot print of MOC-based materials linked with their whole life cycles is by $40-50 \%$ lower than that of PC [8]. The other two phases, Phase 2 $\left(2 \mathrm{Mg}(\mathrm{OH})_{2} \cdot \mathrm{MgCl}_{2} \cdot 4 \mathrm{H}_{2} \mathrm{O}\right)$ and Phase $9\left(9 \mathrm{Mg}(\mathrm{OH})_{2} \cdot \mathrm{MgCl}_{2} \cdot 5 \mathrm{H}_{2} \mathrm{O}\right)$ can be prepared and are stable at elevated temperatures $\left(\sim 100{ }^{\circ} \mathrm{C}\right)[9,10]$. MOC has very specific properties, which make it in some ways superior to PC. The distinctly lower specific density of MOC gives it higher compressive and flexural strength. It has high fire resistance, as well as the resistance to abrasion and low thermal conductivity [11,12]. The curing time of MOC is quite short-phase 5 cures fully after approximately $96 \mathrm{~h}$, phase 3 only in $36 \mathrm{~h}[13,14]$. Primarily, MOC is used as a material for flooring, fire protective systems, grinding wheels, wall insulation and as a material for decorative elements [15-20]. Also, it is suitable for use with many aggregates, e.g., tire rubber, synthetic resin, wood particles or fly ash [21-24].

Another direction of the search for alternative materials is linked to the use of natural sources, which needs to be minimized. In the Portland cement concrete production, the consumption of sand is large, while the raw material is quite uncommon. It is possible to replace the sand with alternative waste materials, such as porcelain electric insulation waste. Porcelain electric insulators have very good mechanical strength. The main phases present in their structure are corundum, cristobalite, mullite, quartz and a glass phase fraction [25]. Porcelain insulators are removed after quite a long time of service as a mechanical support for the conductor and its electrical insulation from the grounded structure. They are mechanically stressed by the weight of the conductor and also, they are exposed to weather fluctuation, which might cause some deterioration of the mechanical properties. However, mostly the insulators are capable of serving elsewhere [26,27]. The replacement of ordinarily used sand with porcelain electric insulator waste in concrete was already studied in the past, showing its ability to partially replace the silica sand [28,29]. Moreover, porcelain waste can be considered as $\mathrm{CO}_{2}$ zero material, when neglecting the energy consumed for its milling.

The objective of this study was the preparation and evaluation of the composite of MOC with porcelain waste sand as a partial replacement for natural sand. The obtained samples were studied using a broad spectrum of analytical methods, to determine their chemical and phase composition, thermal behavior and mechanical properties.

\section{Experimental}

\subsection{Materials and Samples}

MOC composites were produced from caustic $\mathrm{MgO}$ powder, $\mathrm{MgCl}_{2} \cdot 6 \mathrm{H}_{2} \mathrm{O}$ of p.a. purity, silica sand, and ground porcelain insulator waste. $\mathrm{MgO}$ powder was a product of Styromagnesit Steirische Magnesitindustrie Ltd., Oberdorf, Austria. $\mathrm{MgCl}_{2} \cdot 6 \mathrm{H}_{2} \mathrm{O}$ was obtained from the Czech chemical company Lach-Ner, Ltd., Brno Neratovice, Czech Republic. As reference aggregate, standardized sand originally produced for rendering and plastering mortars was used. It was delivered by Filtrační písky Ltd. (Chlum u Doks, Czech Republic) and contained three sand fractions with the particles in 
the $0-2 \mathrm{~mm}$ range. The particular sand fractions were mixed in a weight ratio 1:1:1. For the partial substitution of silica sand, porcelain waste (PW) coming from the replacement of used electrical insulators was used in the composition of the developed composites. The porcelain insulators were originally produced by the company Elektroporcelán a.s. (Louny, Czech Republic). At first, they were roughly crushed and then dry milled using a ball mill type Los Angeles.

The composite mixtures were proportioned as introduced in Table 1 . The reference composite was labelled as MOC-Ref. In accordance with sand substitution ratio, materials with incorporated porcelain waste were marked as MOC-SPW5, MOC-SPW10, and MOC-SPW15, respectively. The MOC composites was prepared as prescribed in the EN 14016-2 [30].

Table 1. Composition of magnesium oxychloride cement (MOC) composites (g).

\begin{tabular}{lccccc}
\hline \multicolumn{1}{c}{ Material } & MgO & $\mathbf{M g C l}_{\mathbf{2}}$ & Water & Silica Sand & Porcelain Waste \\
\hline MOC-Ref & 1541.25 & 682.85 & 567.25 & $3 \times 1125.00$ & - \\
MOC-SPW5 & 1541.25 & 682.85 & 567.25 & $3 \times 1068.75$ & 141.67 \\
MOC-SPW10 & 1541.25 & 682.85 & 567.25 & $3 \times 1012.50$ & 283.33 \\
MOC-SPW15 & 1541.25 & 682.85 & 567.25 & $3 \times 956.25$ & 425.00 \\
\hline
\end{tabular}

The plastic molds were provided with mineral oil. The samples were $40 \mathrm{~mm} \times 40 \mathrm{~mm} \times 160 \mathrm{~mm}$ prisms. The casted composite samples were unmolded after $24 \mathrm{~h}$ and left to cure for 27 days at laboratory at $T=(23 \pm 2){ }^{\circ} \mathrm{C}, R H=(50 \pm 5 \%)$.

\subsection{Methods}

The individual methods used are described in detail in the Supporting Information file. The chemical composition of PW, sand and MgO was determined by XRF (X-Ray fluorescence, PANalytical, Almelo, Netherlands). Phase composition of PW was studied by X-ray powder diffraction (XRD, Bruker AXS GmbH, Karlsruhe, Germany) [31]. The morphology was studied by scanning electron microscopy (SEM, Tescan Lyra 3 dual beam microscope, Tescan Brno, s.r.o., Brno, Czech Republi) [32]. Specific density, loose bulk density, and Blaine fineness of $\mathrm{MgO}$, silica sand, and PW were also tested. For the specific density assessment, an automatic helium pycnometer was used. The particle size distribution of PW was analyzed by laser diffraction, while the grain size distribution of silica sand was determined in the standard sieve test. The workability of fresh mixtures was verified using a flow table test.

The hardened composites were tested after 28 days maturing under laboratory conditions. Phase composition was tested on MOC/PW pastes only as the silica peaks would overlap the XRD peaks of precipitated MOC phases. X-ray powder diffraction of MOC/PW pastes was performed similarly as in the analysis of PW. The structural parameters and mechanical resistance of MOC composites were investigated [33]. Mercury intrusion porosimetry (MIP) was used for the detailed investigation of the pore structure of hardened composites. The hygric parameters of developed composites were determined as originally introduced in our previous publication [34]. Among thermal parameters of composites, dry thermal conductivity $\lambda\left(\mathrm{W} \cdot \mathrm{m}^{-2} \cdot \mathrm{K}^{-1}\right)$, thermal diffusivity $a\left(\mathrm{~m}^{2} \cdot \mathrm{s}^{-1}\right)$, and volumetric heat capacity $c_{v}\left(\mathrm{~J} \cdot \mathrm{m}^{-3} \cdot \mathrm{K}^{-1}\right)$ were tested. The simultaneous thermal analysis (STA) of the matured materials and their FT-IR (VERTEX 70 FT-IR, Bruker Corporation, Mannheim, Germany) analysis were also conducted.

\section{Results and Discussion}

The chemical composition of quartz sand, porcelain waste (PW), and $\mathrm{MgO}$ measured in XRF analysis is introduced in Table 2. Based on XRF measurements, the main oxides forming the studied materials were detected. For PW, the prevailing constituents were $\mathrm{SiO}_{2}$ and $\mathrm{Al}_{2} \mathrm{O}_{3}$ that represented $93.2 \mathrm{wt}$. \% of porcelain waste. 
Table 2. Chemical composition of caustic $\mathrm{MgO}$, quartz sand, and PW (wt. \%).

\begin{tabular}{cccc}
\hline Substance & MgO & Quartz Sand & PW \\
\hline $\mathrm{SiO}_{2}$ & 3.8 & 96.3 & 63.9 \\
$\mathrm{CaO}$ & 5.2 & - & 0.5 \\
$\mathrm{Al}_{2} \mathrm{O}_{3}$ & 6.0 & 3.1 & 29.3 \\
$\mathrm{MgO}$ & 80.5 & 0.4 & 0.5 \\
$\mathrm{Fe}_{2} \mathrm{O}_{3}$ & 3.8 & - & 1.1 \\
$\mathrm{~K}_{2} \mathrm{O}$ & - & - & 2.3 \\
$\mathrm{SO}_{3}$ & 0.4 & - & - \\
$\mathrm{Na}_{2} \mathrm{O}$ & - & - & 1.9 \\
$\mathrm{TiO}_{2}$ & - & 0.1 & 0.3 \\
$\mathrm{P}_{2} \mathrm{O}_{5}$ & - & - & - \\
\hline
\end{tabular}

The phase analysis of PW was studied using XRD. The two main crystalline phases that were present in the sample were identified as silicon oxide (ICDD 01-070-3755) and mullite (ICDD 01-074-4143). Also the amorphous background was obtained, due to the presence of glassy $\mathrm{SiO}_{2}$ with alkali admixtures. Obtained results are shown in Figure S1 (Supporting Information).

SEM micrographs were acquired to study the microstructure and particle size of the porcelain waste (PW). While some particles have a few microns in diameter, other particles had diameters higher than $50 \mu \mathrm{m}$. Particle size distribution was also measured by laser diffraction. The EDS was also measured to obtain the chemical composition of PW. EDS detected the presence of Si (35.3 wt. \%), $\mathrm{Al}(12.9$ wt. \%), O (44.7 wt. \%), K (3.5 wt. \%), C (2.0 wt. \%), and Na (1.4 wt. \%). SEM images together with EDS results are depicted in Figure S2 (Supporting Information).

Data provided by laser particle size distribution analysis is presented in Figure 1. For comparison, particle size distribution of used sand measured by the standard sieve analysis is also presented. Porcelain waste was greatly finer in comparison with quartz sand. The particle size distribution parameters of porcelain waste were $d_{10}=19.9 \mu \mathrm{m}, d_{50}=59.3 \mu \mathrm{m}$ and $d_{90}=118.9 \mu \mathrm{m}$.

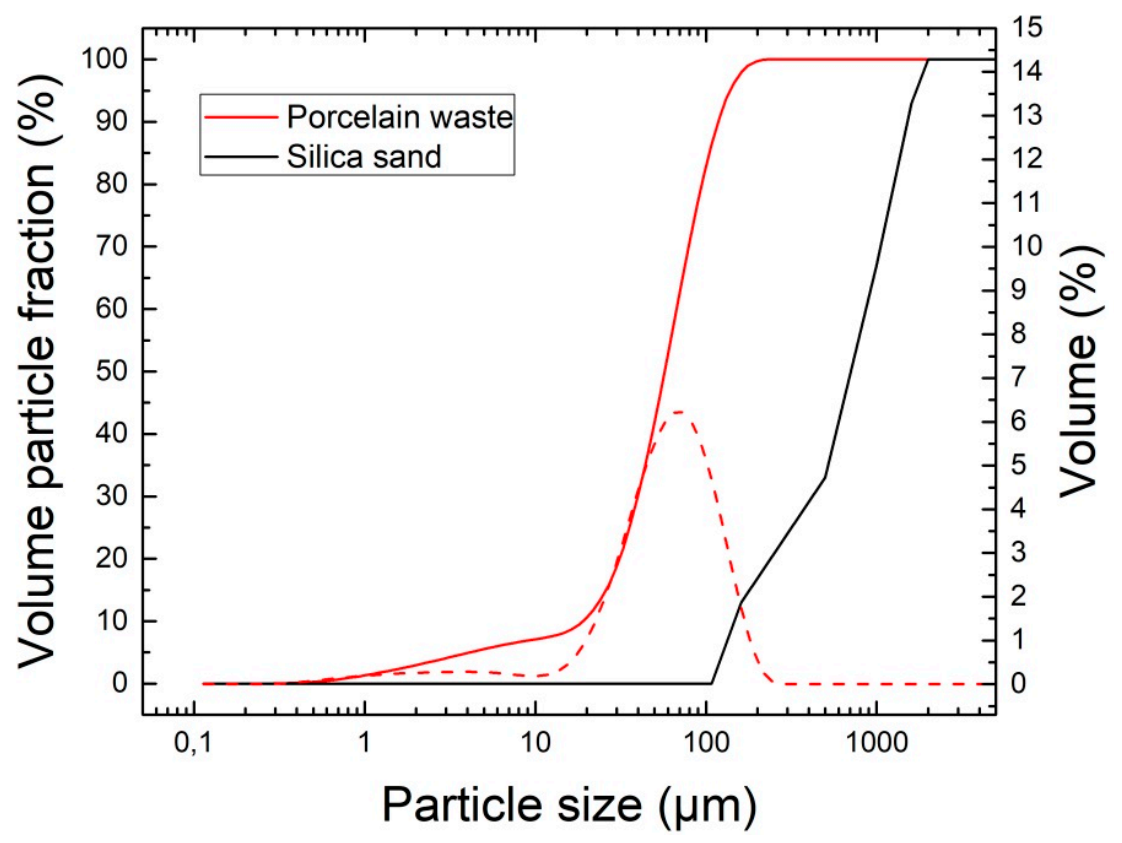

Figure 1. Particle size distribution of PW and silica sand.

Specific density, loose bulk density, and Blaine fineness of $\mathrm{MgO}$, quartz sand, and $\mathrm{PW}$ are summarized in Table 3. The highest specific density exhibited $\mathrm{MgO}$ which possessed also the higher Blaine specific surface. Porcelain waste had greatly lower loose bulk density compared to quartz sand that was the result of its presumed porosity. 
Table 3. Basic physical parameters of $\mathrm{MgO}$, quartz sand, and porcelain waste.

\begin{tabular}{|c|c|c|c|}
\hline Material & $\begin{array}{c}\text { Loose Bulk Density } \\
\left(\mathrm{kg} \cdot \mathrm{m}^{-3}\right)\end{array}$ & $\begin{array}{l}\text { Specific Density } \\
\left(\mathrm{kg} \cdot \mathrm{m}^{-3}\right)\end{array}$ & $\begin{array}{c}\text { Blaine Specific Surface } \\
\left(\mathrm{m}^{2} \cdot \mathrm{kg}^{-1}\right)\end{array}$ \\
\hline $\mathrm{MgO}$ & 843 & 3337 & 698 \\
\hline Quartz Sand & 1663 & 2651 & - \\
\hline Porcelain Waste & 1164 & 2506 & 304 \\
\hline
\end{tabular}

The basic structural parameters of hardened samples and workability characterized by spread diameter are introduced in Table 4. Despite the assumed higher specific surface of PW compared to quartz sand, its 5\% replacement with porcelain waste slightly improved the workability of prepared composite mortar which was a consequence of the improved packing density and thus rheology of the fresh mixture. On the other hand, for higher replacement ratio of sand with PW, the spread diameter decreased and thus the workability of composites was worse than that obtained for control material MOC-ref. This was due to the higher dosage of PW and its high specific surface which partially blocked the batch water molecules within samples mixing. In comparison with control composite MOC-Ref, the values of specific density were lower for all MOC composites with sand replacement. The differences were typically $\sim 7-8 \%$. This was in agreement with the observed porosity of these materials, which was much lower compared to control composite. Surprisingly, the lower workability of MOC-SPW10 and MOC-SPW15 had no negative influence on their final porosity as its differences were for materials with PW low, especially taking into consideration the expanded combined uncertainty of porosity test. Quantitatively, the lowest porosity among tested composites reached material MOC-SP10, whose porosity was of about $71.1 \%$ lower than measured for reference composite.

Table 4. Basic structural characteristics of MOC composites.

\begin{tabular}{|c|c|c|c|c|}
\hline Material & $\begin{array}{l}\text { Spread Diameter } \\
(\mathrm{mm})\end{array}$ & $\begin{array}{c}\text { Bulk Density } \rho_{\mathrm{b}} \\
\quad\left(\mathrm{kg} \cdot \mathrm{m}^{-3}\right)\end{array}$ & $\begin{array}{c}\text { Specific Density } \rho_{s} \\
\left(\mathbf{k g} \cdot \mathrm{m}^{-3}\right)\end{array}$ & $\begin{array}{l}\text { Porosity } \varphi \\
\text { (\%) }\end{array}$ \\
\hline MOC-Ref & $165 / 165 \pm 5$ & $2123 \pm 30$ & $2436 \pm 29$ & $12.8 \pm 0.3$ \\
\hline MOC-SPW5 & $175 / 175 \pm 5$ & $2163 \pm 30$ & $2262 \pm 27$ & $4.4 \pm 0.1$ \\
\hline MOC-SPW10 & $160 / 160 \pm 5$ & $2158 \pm 30$ & $2241 \pm 27$ & $3.7 \pm 0.1$ \\
\hline MOC-SPW15 & $140 / 140 \pm 5$ & $2143 \pm 30$ & $2236 \pm 27$ & $4.2 \pm 0.1$ \\
\hline
\end{tabular}

The phase composition of hardened composites was determined using XRD. The results showed the presence of the MOC- 518 (Phase $5,5 \mathrm{Mg}(\mathrm{OH})_{2} \cdot \mathrm{MgCl}_{2} \cdot 8 \mathrm{H}_{2} \mathrm{O}$ ), magnesium oxide, silicon oxide, mullite and chlorartinite, which was present due to the carbonation of MOC. The obtained diffraction patterns can be seen in Figure 2.

Mechanical resistance of hardened MOC composites was characterized by flexural strength $R_{f}$, compressive strength $R_{c}$, and Young's modulus of elasticity $E_{d}$. As shown in Table 5, all samples reached high compressive strength which is usual for this type of material $[11,35]$ and enables its application in load bearing structures. Both flexural and compressive strength were even higher than observed for 28 day samples of typical ordinary PC concrete by Chen et al. [36]. The highest mechanical resistance exhibited material MOC-SPW10. This was assigned to its lowest porosity and presumed activity of PW components with products of MOC precipitation, such as with $\mathrm{Mg}(\mathrm{OH})_{2}$. On the contrary, $5 \%$ silica sand replacement with PW resulted in a drop in all examined mechanical parameters. However, the decrease in mechanical resistance was not significant and was assigned to the lower strength of ceramic waste compared to quartz sand. Also, $15 \%$ replacement of quart sand gave material with high mechanical strength and elastic modulus. High flexural/compressive strength ratio (32.7 for MOC-Ref, 33.2 for MOC-SPW5, 31.3 for MOC-SPW10, and 33.0 for MOC-SPW15) and high Young's modulus are also typical functional properties of MOC composites [37]. The high flexural compressive ratio was typically higher that reported for ordinary PC concrete which is usually in the interval from 0.1 to 0.2 [38]. 


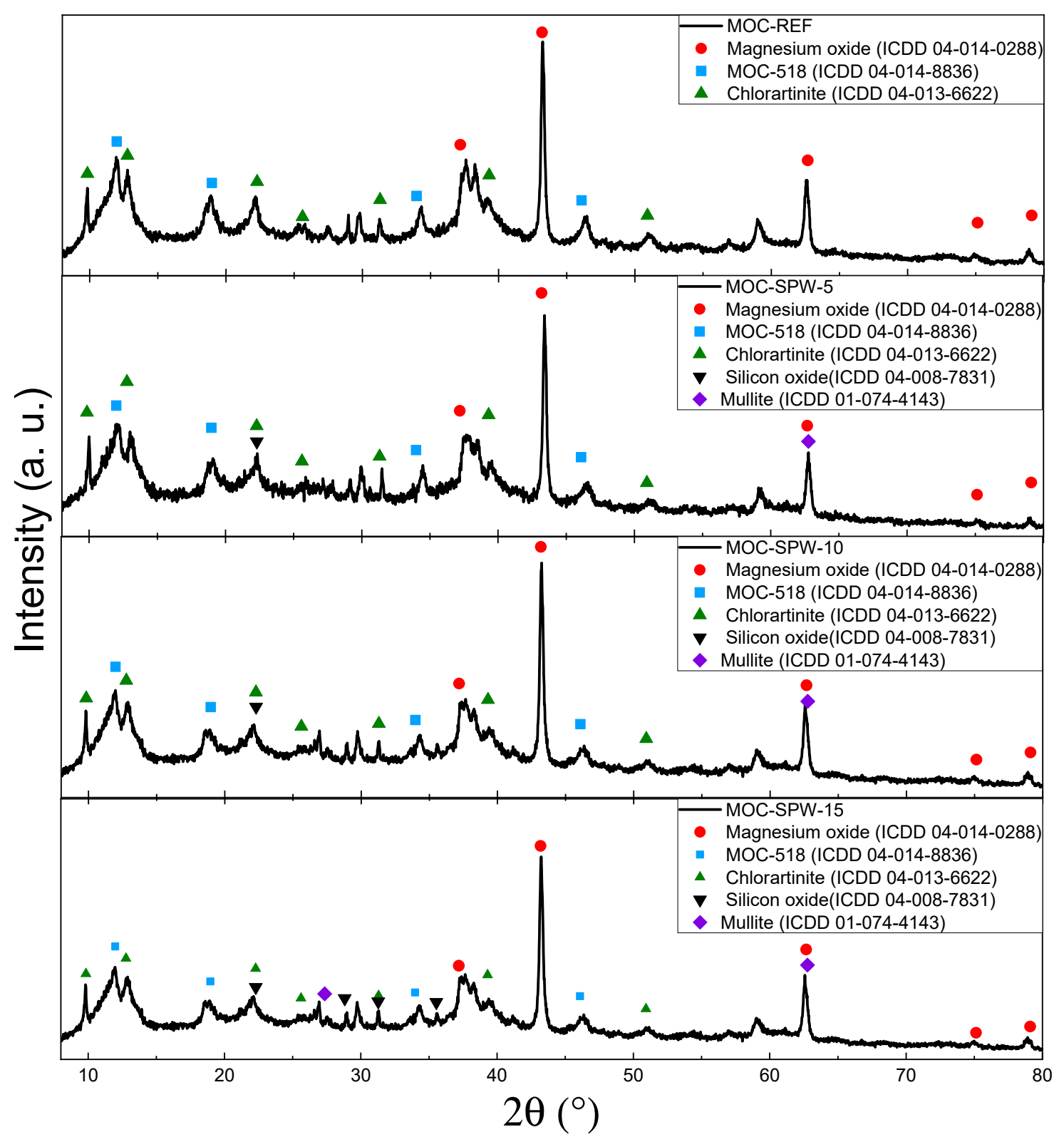

Figure 2. Diffraction patterns of MOC-REF, MOC-SPW5, MOC-SPW10 and MOC-SPW15.

Table 5. Mechanical parameters of MOC composites.

\begin{tabular}{lccc}
\hline Material & $\begin{array}{c}\text { Flexural Strength } \boldsymbol{R}_{\boldsymbol{f}} \\
\mathbf{( M P a )}\end{array}$ & $\begin{array}{c}\text { Compressive strength } \boldsymbol{R}_{\boldsymbol{c}} \\
\mathbf{( M P a )}\end{array}$ & $\begin{array}{c}\text { Young's Modulus } \boldsymbol{E}_{\boldsymbol{d}} \\
(\mathbf{G P a})\end{array}$ \\
\hline MOC-Ref & $25.1 \pm 0.4$ & $76.7 \pm 1.2$ & $40.5 \pm 0.9$ \\
MOC-SPW5 & $24.7 \pm 0.3$ & $74.3 \pm 1.0$ & $40.1 \pm 0.9$ \\
MOC-SPW10 & $26.8 \pm 0.4$ & $85.5 \pm 1.2$ & $42.5 \pm 1.0$ \\
MOC-SPW15 & $25.6 \pm 0.4$ & $77.5 \pm 1.1$ & $41.3 \pm 1.0$ \\
\hline
\end{tabular}

Figure 3 presents the cumulative pore volume curves of studied samples obtained by MIP analysis. Additionally, the parameters of pore size distribution are summarized in Table 6. 


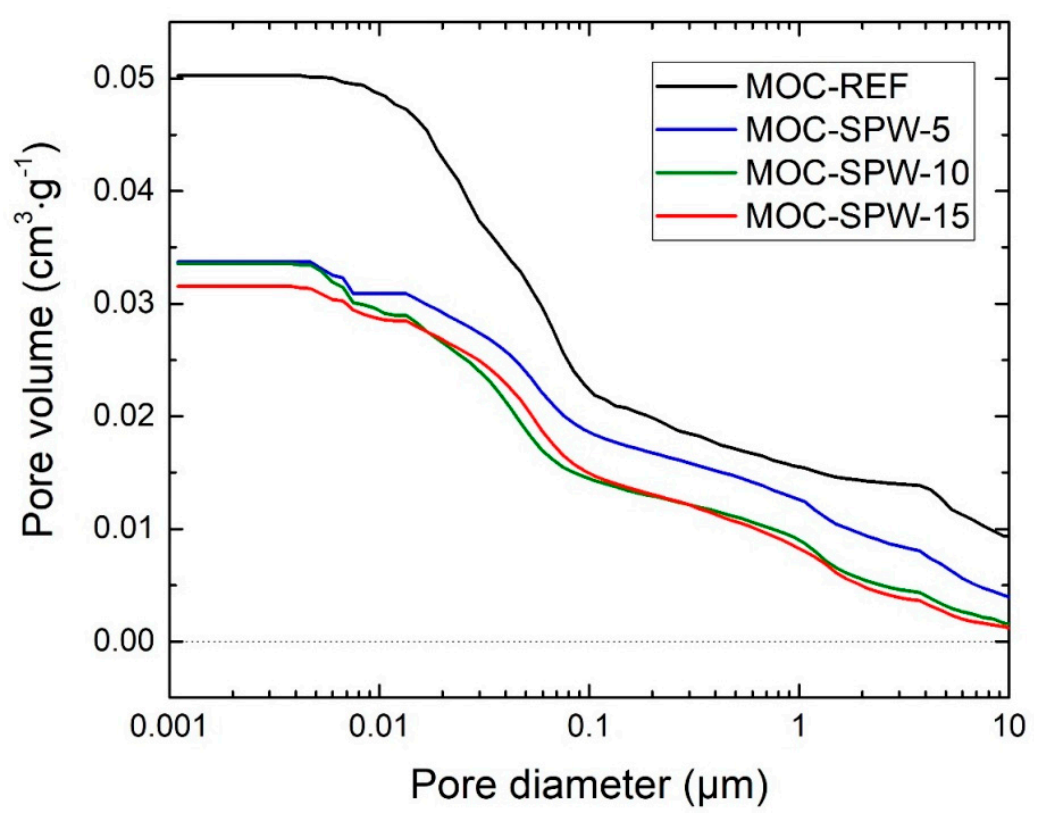

Figure 3. Cumulative pore volume curves of examined composites.

Table 6. Parameters of pore volume distribution.

\begin{tabular}{|c|c|c|c|}
\hline $\begin{array}{l}\text { Pore Diameter Range } \\
(\mu \mathrm{m})\end{array}$ & $\begin{array}{l}\text { Specific Vol. } \\
\left(\mathrm{cm}^{3} / \mathrm{g}\right)\end{array}$ & Specific Vol. (\%) & Relative Vol. (\%) \\
\hline \multicolumn{4}{|l|}{ MOC-Ref } \\
\hline $100-10$ & 0.00936 & 18.59 & 18.59 \\
\hline $10-1$ & 0.01542 & 30.60 & 12.01 \\
\hline $1-0.1$ & 0.02186 & 43.40 & 12.80 \\
\hline $0.1-0.01$ & 0.04845 & 96.18 & 52.78 \\
\hline $0.01-0.001$ & 0.05027 & 99.79 & 3.61 \\
\hline \multicolumn{4}{|l|}{ MOC-SPW5 } \\
\hline $100-10$ & 0.00382 & 11.28 & 11.28 \\
\hline $10-1$ & 0.01242 & 36.67 & 25.39 \\
\hline $1-0.1$ & 0.01837 & 54.24 & 17.58 \\
\hline $0.1-0.01$ & 0.03090 & 91.24 & 37.00 \\
\hline $0.01-0.001$ & 0.03372 & 99.55 & 8.31 \\
\hline \multicolumn{4}{|l|}{ MOC-SPW10 } \\
\hline $100-10$ & 0.00109 & 3.44 & 3.44 \\
\hline $10-1$ & 0.00803 & 25.42 & 21.98 \\
\hline $1-0.1$ & 0.01470 & 46.56 & 21.14 \\
\hline $0.1-0.01$ & 0.02854 & 90.37 & 43.81 \\
\hline $0.01-0.001$ & 0.03153 & 99.83 & 9.46 \\
\hline \multicolumn{4}{|l|}{ MOC-SPW15 } \\
\hline $100-10$ & 0.00149 & 4.44 & 4.44 \\
\hline $10-1$ & 0.00871 & 25.94 & 21.51 \\
\hline $1-0.1$ & 0.01432 & 42.65 & 16.71 \\
\hline $0.1-0.01$ & 0.02914 & 86.82 & 44.17 \\
\hline $0.01-0.001$ & 0.03355 & 99.95 & 13.13 \\
\hline
\end{tabular}


The cumulative pore volume curves followed the trend of the total open porosity of tested materials introduced in Table 4. Taking into account the mass of MIP samples and measurement uncertainty, the MIP data were in a good qualitative and quantitative agreement with that obtained based on gravimetric and helium pycnometry tests. It can be seen that the presence of $\mathrm{PW}$ in the composition of composites led to a significant decrease of the pore volume in comparison with the reference material. The specific volume of pores in MOC-SPW 5, MOC-SPW10 and MOC-SPW15 decreased to $67.1 \%$, $62.7 \%$ and $66.7 \%$ of MOC-Ref value, respectively. As regards the pore size terminology in MOC-based composites, individual papers vary. Li et al. [39] stated that volume fraction of pores with diameter $>0.1 \mu \mathrm{m}$ (large pores) is responsible for mechanical properties while pores with diameter $<0.1 \mu \mathrm{m}$ (small pores) affect mainly the water resistance. In our case, MOC-Ref sample exhibited the highest volume proportion of both small and large pores. After the addition of PW into the mixture, the volume of large pores as well as of small pores decreased. In this sense the data obtained by MIP confirmed that modification of composites composition by PW can optimize the pore structure of MOC-based structure, which resulted in the improvement of both mechanical parameters and water resistance.

Parameters characterizing liquid water transport in studied MOC composites are presented in Table 7. Application of PW resulted in a notable drop of water absorption rate which was associated with the reduction of porosity and lower pore size. The water absorption coefficient $A_{w}$ was reduced by 70.3\% for MOC-SPW5, 73.6\% for MOC-SPW10, and 82.1\% for MOC-SPW15 respectively. Similarly, the sorptivity was reduced. The $24 \mathrm{~h}$ water absorption $W_{a}$ was 52.3\% (MOC-SPW5), 48.4 (MOC-SPW10), and 51.2\% (MOC-SPW15) of the reference value. The apparent moisture diffusivity was also greatly reduced. As the water transport was significantly decelerated and limited by the use of PW in the composition of developed composites, their water resistance and thus durability was improved which is beneficial for application of these advanced materials in construction practice.

Table 7. Hygric parameters of MOC composites.

\begin{tabular}{|c|c|c|c|c|}
\hline Material & $\begin{array}{l}\text { Water Absorption Coefficient } \\
A_{\mathrm{w}} \times 10^{-3} \\
\left(\mathrm{~kg} \mathrm{~m}^{-2} \cdot \mathrm{s}^{-1 / 2}\right)\end{array}$ & $\begin{array}{l}\text { Sorptivity } \\
S_{\mathrm{w}} \times 10^{-6} \\
\left(\mathrm{~m} \cdot \mathrm{s}^{-1 / 2}\right)\end{array}$ & $\begin{array}{c}\text { Moisture Diffusivity } \\
K_{\text {app }} \\
\left(\mathrm{m} \cdot \mathrm{s}^{-2}\right) \times 10^{-9}\end{array}$ & $\begin{array}{c}24 \text { h Water } \\
\text { Absorption } W_{a} \\
(\%)\end{array}$ \\
\hline MOC-Ref & $6.1 \pm 0.14$ & $6.1 \pm 0.14$ & $4.2 \pm 0.2$ & $2.58 \pm 0.03$ \\
\hline MOC-SPW5 & $1.8 \pm 0.04$ & $1.8 \pm 0.04$ & $2.9 \pm 0.1$ & $1.35 \pm 0.02$ \\
\hline MOC-SPW10 & $1.1 \pm 0.03$ & $1.1 \pm 0.03$ & $1.5 \pm 0.1$ & $1.25 \pm 0.02$ \\
\hline MOC-SPW15 & $1.6 \pm 0.03$ & $1.6 \pm 0.03$ & $2.5 \pm 0.1$ & $1.32 \pm 0.02$ \\
\hline
\end{tabular}

Thermal parameters characterizing the ability of studied composite materials to transport and store heat are given in Table 8. Before testing, specimens were dried in a vacuum chamber at temperature $60^{\circ} \mathrm{C}$ until their steady state mass was reached. For the explanation of measured data, information on thermal parameters of quartz sand and PW is also provided. While the reference sample reached thermal conductivity of $3.17 \mathrm{~W} \cdot \mathrm{m}^{-1} \cdot \mathrm{K}^{-1}$, the thermal conductivity of material with $5 \%$ replacement of sand slightly increased by $3.5 \%$. Surprisingly, with a higher replacement ratio the thermal conductivity drop continued despite the fact that the lowest porosity was recorded for MOC-SPW10. This materials' thermal performance was attributed with much lower thermal conductivity of porcelain waste compared to quartz sand. As the porosity of all researched materials was low, this effect predominated over the porosity contribution to the total thermal conductivity and thus thermal diffusivity. The volumetric heap capacity was almost similar for all examined composites as the differences in heat storage were for both fillers low. Although MOC has been known since 1867, very few researchers have focused on the thermal characteristics of this type of material. Certain exception represent studies $[36,40]$, where authors tested MOC-based materials with silica sand aggregate and bulk density of $\sim 2100 \mathrm{~kg} \cdot \mathrm{m}^{-3}$. They reported on the thermal conductivity of MOC composites in the range of $2.1-2.2 \mathrm{~W} \cdot \mathrm{m}^{-1} \cdot \mathrm{K}^{-1}$, which was lower compared to the thermal conductivity values presented in this paper. 
Table 8. Thermal characteristics of MOC composites.

\begin{tabular}{|c|c|c|c|}
\hline Material & $\begin{array}{c}\lambda \\
\left(\mathrm{W} \cdot \mathrm{m}^{-1} \cdot \mathrm{K}^{-1}\right)\end{array}$ & $\begin{array}{c}a \\
\times 10^{-6}\left(\mathrm{~m}^{2} \cdot \mathrm{s}^{-1}\right)\end{array}$ & $\begin{array}{c}c_{v} \\
\left(\mathrm{MJ} \cdot \mathrm{m}^{-3} \cdot \mathrm{K}^{-1}\right)\end{array}$ \\
\hline Silica sand & 0.5 & 1.7 & 0.3 \\
\hline PW & 0.2 & 0.5 & 0.3 \\
\hline MOC-Ref & 3.2 & 1.5 & 2.1 \\
\hline MOC-SPW5 & 3.3 & 1.5 & 2.2 \\
\hline MOC-SPW10 & 3.2 & 1.5 & 2.1 \\
\hline MOC-SPW15 & 3.0 & 1.4 & 2.1 \\
\hline
\end{tabular}

The collected FT-IR spectra (Figure 4) of tested magnesium oxychloride cement composites show the absorption bands between $400-800 \mathrm{~cm}^{-1}$ which can be attributed to the stretching and bending vibrations of $\mathrm{Si}-\mathrm{O}, \mathrm{Al}-\mathrm{O}, \mathrm{Mg}-\mathrm{O}$, and $\mathrm{Mg}-\mathrm{Cl}$ of the lattice, while the absorption band at $845 \mathrm{~cm}^{-1}$ can be assigned to the characteristic absorption peak of $\mathrm{Mg}-\mathrm{O}$ in cubic structure $[13,41]$. The absorption band at $1021 \mathrm{~cm}^{-1}$ is typical for stretching vibration of Si-O mode of magnesium silicate hydrate [42]. The absorption bands near the $1600 \mathrm{~cm}^{-1}$ are caused due to $\mathrm{H}_{2} \mathrm{O}$ bending mode vibration in $\mathrm{MgCl}_{2} \cdot 8 \mathrm{H}_{2} \mathrm{O}$. The absorption band at $1149 \mathrm{~cm}^{-1}$ and stronger at $1423 \mathrm{~cm}^{-1}$ are attributed to the stretching vibration of $\mathrm{C}=\mathrm{O}$ in carbonates, resulting from the presence of $\mathrm{MgCO}_{3}$ in light burned magnesia and from the carbonation reaction [43]. The spectral range around $2000 \mathrm{~cm}^{-1}$ includes a lot of absorption bands coming from the bending and rocking vibrations of $\mathrm{O}-\mathrm{H}$ in $\mathrm{H}_{2} \mathrm{O}$ and $\left(\mathrm{Mg}(\mathrm{OH})_{2}\right)$ and also carbonates overtones. As the intensities of these absorption bands were low, they were not analyzed in detail. The absorption bands in the range of $3300-3700 \mathrm{~cm}^{-1}$ are contributed by the symmetric and asymmetric stretching mode of $\mathrm{O}-\mathrm{H}$ bonds in $\mathrm{H}_{2} \mathrm{O}$ and $\mathrm{Mg}(\mathrm{OH})_{2}$ [42]. These are reduced after adding the porcelain waste due to inhibition the formation of $\mathrm{Mg}(\mathrm{OH})_{2}$ in hardened $\mathrm{MOC}$ composites. It is believed to leads to improve the mechanical parameters of composites with PW [42].

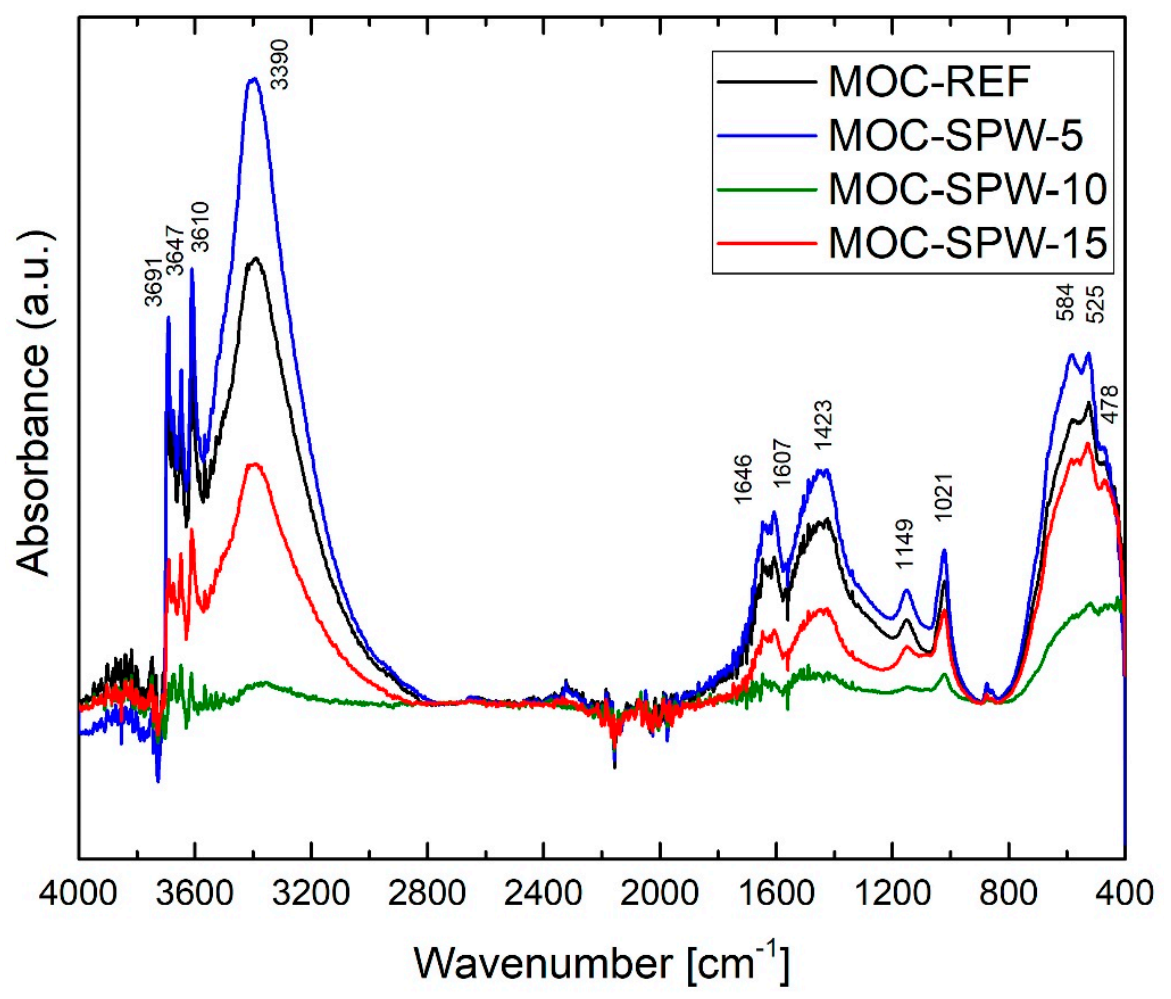

Figure 4. IR spectra of MOC-REF, MOC-SPW5, MOC-SPW10, and MOC-SPW15. 
Thermal behavior of the investigated materials at high temperatures was studied using STA (Figure 5). All analyzed samples showed very similar behavior; the overall weight decrease was in the range between $29.6 \mathrm{wt}$. \% to $33.9 \mathrm{wt}$. \%. A slightly lower value was obtained for the sample MOC-SPW-15 with the highest PW content, which was caused due to high thermal stability of the phases present in PW. In all samples, the gradual decomposition of phase MOC-518 was obtained, that was already described in the literature $[44,45]$. During the heating, eight water molecules were released from $5 \mathrm{Mg}(\mathrm{OH})_{2} \cdot \mathrm{MgCl}_{2} \cdot 8 \mathrm{H}_{2} \mathrm{O}$ to $300{ }^{\circ} \mathrm{C}$. Further heating led to the complete decomposition of this phase forming $\mathrm{MgO}$. This process was associated with the release of water and hydrochloric acid [13].
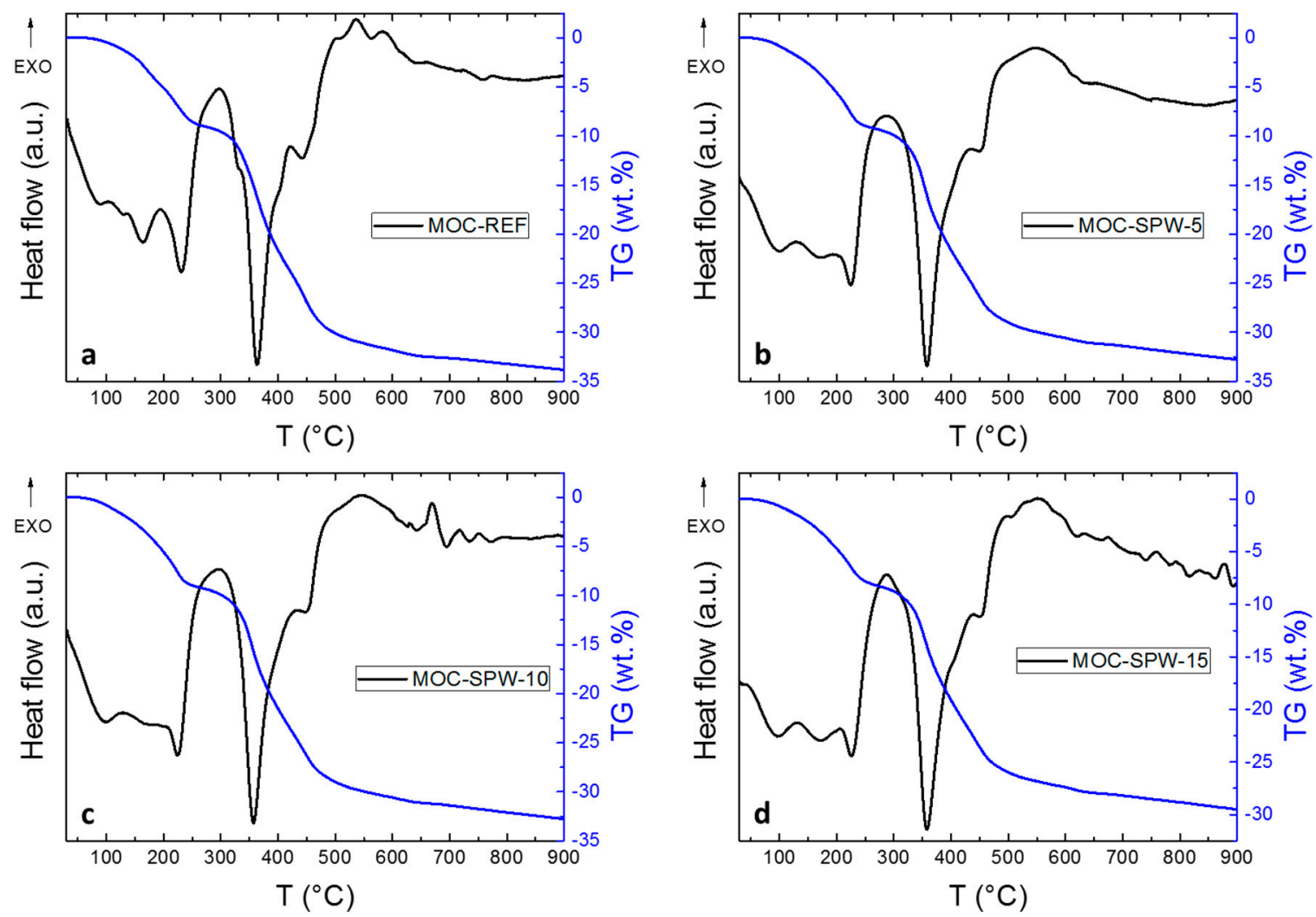

Figure 5. STA of (a) MOC-REF, (b) MOC-SPW5, (c) MOC-SPW10, and (d) MOC-SPW15.

\section{Conclusions}

Combination of laboratory processed porcelain waste and natural quartz sand was used as a blended filler of MOC composites. The developed materials were characterized by their structural, parameters and hygrothermal performance together with the analysis of their phase composition and thermal stability. As MOC is low carbon binder it can potentially represent an interesting alternative for Portland cement-based materials whose production enormously depletes natural resources and excessively generates greenhouse gases. The performed experiments and acquired data allowed to draw the following conclusions:

- a 5\% substitution of silica sand with PW moderately improved workability of fresh mixture, but the spread diameter of composites with a higher dosage of PW was slightly lower than that measured for control mixture MOC-Ref;

- $\quad$ the usage of waste porcelain greatly decreased the porosity of composite matrix;

- the drop in porosity resulted in high mechanical resistance and reduced and decelerated water imbibition;

- the $10 \%$ sand substitution with PW brought the best mechanical resistance and the lowest water absorption due to the formation of amorphous phases (undetectable by XRD) from the reaction 
between precipitated MOC products (presumably $\left.\mathrm{Mg}(\mathrm{OH})_{2}\right)$ and $\mathrm{PW}$ forming phases which are partially reactive, the results are hydrated water insoluble aluminosilicates;

- in case of the thermal performance of the examined composites, the low thermal conductivity of PW was the contradictory parameter to porosity;

- due to high thermal stability of the phases present in PW, the thermal decomposition of composites slightly decreased with PW dosage.

It can be concluded that the partial substitution of quartz sand in MOC composites enabled materials possessing interesting and advanced function and technical parameters to develop. The assessed materials' properties can be further exploited in design and production of high-performance construction materials with specific application potential. The main benefits of the developed composites are low carbon footprint, low porosity that limits the risk of water damage, high mechanical resistance, and application of waste or secondary raw material (PW) in their composition. Moreover, the properties of MOC matrix with sand/porcelain waste filler can be effectively modified, e.g., by the addition of lightweight aggregate which could enhance the thermal insulation behavior of final composites. This will be the objective of future studies.

Supplementary Materials: The following are available online at http://www.mdpi.com/2227-9717/8/7/829/s1, Figure S1: Diffraction pattern of PW, Figure S2: SEM micrographs with different magnifications and EDS element maps of PW.

Author Contributions: Conceptualization, M.P. and Z.P.; methodology, M.P., O.J., Z.P.; formal analysis, A.P., M.Z., M.L., O.J., Z.P.; investigation, A.P., M.P., M.Z., M.L., A.-M.L.; data curation, M.P., O.J., Z.P.; writing-original draft preparation, A.P., M.P., A.-M.L., O.J., Z.P.; writing—review and editing, M.P., O.J., Z.P.; supervision, M.P., O.J., Z.P.; project administration, O.J., M.P.; All authors have read and agreed to the published version of the manuscript.

Funding: This research was funded by Czech Science Foundation under project No 19-00262S—Reactive magnesia cements-based composites with selected admixtures and additives. This research has been also partially supported by the Grant Agency of the Czech Technical University in Prague, grant No. SGS20/153/OHK1/3T/11.

Acknowledgments: The technical support provided by Pavel Košata from the Faculty of Civil Engineering, CTU in Prague, is greatly acknowledged.

Conflicts of Interest: The authors declare no conflict of interest. The funders had no role in the design of the study; in the collection, analyses, or interpretation of data; in the writing of the manuscript, or in the decision to publish the results.

\section{References}

1. Bhagath Singh, G.V.P.; Subramaniam, K.V.L. Production and characterization of low-energy Portland composite cement from post-industrial waste. J. Clean. Prod. 2019, 239, 118024. [CrossRef]

2. Souto-Martinez, A.; Arehart, J.H.; Srubar, W.V. Cradle-to-gate $\mathrm{CO}_{2}$ e emissions vs. in situ $\mathrm{CO}_{2}$ sequestration of structural concrete elements. Energy Build. 2018, 167, 301-311. [CrossRef]

3. Sorel, S. On a new magnesium cement. CR Acad. Sci. 1867, 65, 102-104.

4. Bilinski, H.; Matković, B.; Mažuranić, C.; Žunić, T.B. The formation of magnesium oxychloride phases in the systems $\mathrm{MgO}-\mathrm{MgCl}_{2}-\mathrm{H}_{2} \mathrm{O}$ and $\mathrm{NaOH}-\mathrm{MgCl}_{2}-\mathrm{H}_{2} \mathrm{O}$. J. Am. Ceram. Soc. 1984, 67, 266-269. [CrossRef]

5. Jankovský, O.; Lojka, M.; Lauermannová, A.-M.; Antončík, F.; Pavlíková, M.; Pavlik, Z.; Sedmidubský, D. Carbon Dioxide Uptake by MOC-Based Materials. Appl. Sci. 2020, 10, 2254. [CrossRef]

6. Matkovic, B.; Young, J. Microstructure of magnesium oxychloride cements. Nat. Phys. Sci. 1973, $246,79$. [CrossRef]

7. Urwongse, L.; Sorrell, C.A. The System $\mathrm{MgO}-\mathrm{MgCl}_{2}-\mathrm{H}_{2} \mathrm{O}$ at $23^{\circ}$ C. J. Am. Ceram. Soc. 1980, 63, 501-504. [CrossRef]

8. Tang, S.; Hu, Y.; Ren, W.; Yu, P.; Huang, Q.; Qi, X.; Li, Y.; Chen, E. Modeling on the hydration and leaching of eco-friendly magnesium oxychloride cement paste at the microscale. Constr. Build. Mater. 2019, 204, 684-690. [CrossRef]

9. Dinnebier, R.E.; Freyer, D.; Bette, S.; Oestreich, M. $9 \mathrm{Mg}(\mathrm{OH})_{2} \cdot \mathrm{MgCl}_{2} \cdot 4 \mathrm{H}_{2} \mathrm{O}$, a High Temperature Phase of the Magnesia Binder System. Inorg. Chem. 2010, 49, 9770-9776. [CrossRef] 
10. Dinnebier, R.E.; Oestreich, M.; Bette, S.; Freyer, D. $2 \mathrm{Mg}(\mathrm{OH})_{2} \cdot \mathrm{MgCl}_{2} \cdot 2 \mathrm{H}_{2} \mathrm{O}$ and $2 \mathrm{Mg}(\mathrm{OH})_{2} \cdot \mathrm{MgCl}_{2} \cdot 4 \mathrm{H}_{2} \mathrm{O}$, Two High Temperature Phases of the Magnesia Cement System. Z. Für Anorg. Und Allg. Chem. 2012, 638, 628-633. [CrossRef]

11. Li, G.; Yu, Y.; Li, J.; Wang, Y.; Liu, H. Experimental study on urban refuse/magnesium oxychloride cement compound floor tile. Cem. Concr. Res. 2003, 33, 1663-1668. [CrossRef]

12. Thompson, H.C. Fireproof Product Using Magnesium Oxychloride Cement. U.S. Patent US19455771A, 15 June 1976.

13. Jirickova, A.; Lojka, M.; Lauermannova, A.M.; Antonacik, F.; Sedmidubsky, D.; Pavlikova, M.; Zaleska, M.; Pavlik, Z.; Jankovsky, O. Synthesis, Structure, and Thermal Stability of Magnesium Oxychloride $5 \mathrm{Mg}(\mathrm{OH})_{2}$ $\mathrm{MgCl}_{2} 8 \mathrm{H}_{2} \mathrm{O}$. Appl. Sci. 2020, 10, 15. [CrossRef]

14. Lojka, M.; Jankovský, O.; Jiříčková, A.; Lauermannová, A.-M.; Antončík, F.; Sedmidubský, D.; Pavlík, Z. Thermal Stability and Kinetics of Formation of Magnesium Oxychloride Phase $3 \mathrm{Mg}(\mathrm{OH})_{2} \cdot \mathrm{MgCl}_{2} 8 \mathrm{H}_{2} \mathrm{O}$. Materials 2020, 13, 767. [CrossRef] [PubMed]

15. De Castellar, M.; Lorente, J.; Traveria, A.; Tura, J. Cracks in Sorel's cement polishing bricks as a result of magnesium oxychloride carbonatation. Cem. Concr. Res. 1996, 26, 1199-1202. [CrossRef]

16. Maravelaki-Kalaitzaki, P.; Moraitou, G. Sorel's cement mortars: Decay susceptibility and effect on Pentelic marble. Cem. Concr. Res. 1999, 29, 1929-1935. [CrossRef]

17. Záleská, M.; Pavlíková, M.; Jankovský, O.; Lojka, M.; Pivák, A.; Pavlík, Z. Experimental Analysis of MOC Composite with a Waste-Expanded Polypropylene-Based Aggregate. Materials 2018, 11, 931.

18. Montle, J.; Mayhan, K. The role of magnesium oxychloride as a fire-resistive material. Fire Technol. 1974, 10, 201-210. [CrossRef]

19. Plekhanova, T.; Keriene, J.; Gailius, A.; Yakovlev, G. Structural, physical and mechanical properties of modified wood-magnesia composite. Constr. Build. Mater. 2007, 21, 1833-1838. [CrossRef]

20. Xia, S.; Xing, P.; Gao, S. Studies on the basic compounds of magnesia cement: The thermal behaviour of magnesium oxychlorides. Thermochim. Acta 1991, 183, 349-363. [CrossRef]

21. Biel, T.D.; Lee, H. Magnesium oxychloride cement concrete with recycled tire rubber. Transp. Res. Rec. 1996, 1561, 6-12. [CrossRef]

22. Li, Y.; Yu, H.; Zheng, L.; Wen, J.; Wu, C.; Tan, Y. Compressive strength of fly ash magnesium oxychloride cement containing granite wastes. Constr. Build. Mater. 2013, 38, 1-7. [CrossRef]

23. Liska, M.; Al-Tabbaa, A. Performance of magnesia cements in pressed masonry units with natural aggregates: Production parameters optimisation. Constr. Build. Mater. 2008, 22, 1789-1797. [CrossRef]

24. Siddique, R.; Naik, T.R. Properties of concrete containing scrap-tire rubber-an overview. Waste Manag. 2004, 24, 563-569. [CrossRef]

25. Higuchi, N.; Ogawa, Y.; Takeuchi, S. Porcelain Electric Insulator. U.S. Patent US3860432A, 14 January 1975.

26. Gorur, R.S.; Shaffner, D.; Clark, W.; Vinson, R.; Ruff, D. Utilities Share Their Insulator Field Experience. Transm. Distrib. World 2005, 57, 17.

27. Mishra, A.P.; Gorur, R.S.; Venkataraman, S. Evaluation of Porcelain and Toughened Glass Suspension Insulators Removed from Service. IEEE Trans. Dielectr. Electr. Insul. 2008, 15, 467-475. [CrossRef]

28. Portella, K.; Joukoski, A.; Franck, R.; Derksen, R. Secondary recycling of electrical insulator porcelain waste in Portland concrete structures: Determination of the performance under accelerated aging. Cerâmica 2006, 52, 155-167. [CrossRef]

29. Zimbili, O.; Salim, W.; Ndambuki, M. A review on the usage of ceramic wastes in concrete production. Int. J. Civ. Environ. Struct. Constr. Archit. Eng. 2014, 8, 91-95.

30. EN 14016-2. Binders for Magnesite Screeds-Caustic Magnesia and Magnesium Chloride-Part 2: Test Methods; European Committee for Standardization: Brussels, Belgium, 2004.

31. Pavlíková, M.; Zemanová, L.; Pokorný, J.; Záleská, M.; Jankovský, O.; Lojka, M.; Sedmidubský, D.; Pavlík, Z. Valorization of wood chips ash as an eco-friendly mineral admixture in mortar mix design. Waste Manag. 2018, 80, 89-100. [CrossRef]

32. Bartůněk, V.; Huber, Š.; Sedmidubský, D.; Sofer, Z.; Šimek, P.; Jankovský, O. CoO and $\mathrm{Co}_{3} \mathrm{O}_{4}$ nanoparticles with a tunable particle size. Ceram. Int. 2014, 40, 12591-12595. [CrossRef]

33. Záleská, M.; Pavlíková, M.; Pavlík, Z.; Jankovský, O.; Pokorný, J.; Tydlitát, V.; Svora, P.; Černý, R. Physical and chemical characterization of technogenic pozzolans for the application in blended cements. Constr. Build. Mater. 2018, 160, 106-116. [CrossRef] 
34. Pavlík, Z.; Černý, R. Determination of moisture diffusivity as a function of both moisture and temperature. Int. J. Thermophys. 2012, 33, 1704-1714. [CrossRef]

35. Xu, B.; Ma, H.; Hu, C.; Li, Z. Influence of cenospheres on properties of magnesium oxychloride cement-based composites. Mater. Struct. 2016, 49, 1319-1326. [CrossRef]

36. Chen, Z.; Xu, Y.; Jianmin, H.; Wang, X.; Huang, L.; Zhou, X. Mechanical Properties and Shrinkage Behaviour of Concrte-Containg Graphene-Oxide Nanosheets. Materials 2020, 13, 590. [CrossRef] [PubMed]

37. Misra, A.K.; Mathur, R. Magnesium oxychloride cement concrete. Bull. Mater. Sci. 2007, 30, $239-246$. [CrossRef]

38. Mehta, P.K. Concrete Structure Properties and Materials; Prentice Hall: Engelwood Cliffs, NJ, USA, 1986.

39. Li, Y.; Li, Z.; Pei, H.; Yu, H. The influence of $\mathrm{FeSO}_{4}$ and $\mathrm{KH}_{2} \mathrm{PO}_{4}$ on the performance of magnesium oxychloride cement. Constr. Build. Mater. 2016, 102, 233-238. [CrossRef]

40. Záleská, M.; Pavlíková, M.; Pavlík, Z. Structural, Mechanical and Thermal Properties of Lightweight Magnesium Oxychloride Cement Concrete. Appl. Sci. 2019, 9, 5463. [CrossRef]

41. Singh, B.K.; Tomar, R.; Kumar, S.; Jain, A.; Tomar, B.S.; Manchanda, V.K. Sorption of ${ }^{137}{ }^{C s},{ }^{133}$ Ba and ${ }^{154} \mathrm{Eu}$ by synthesized sodium aluminosilicate (Na-AS). J. Hazard. Mater. 2010, 178, 771-776. [CrossRef]

42. Tironi, A.; Trezza, M.A.; Irassar, E.F.; Scian, A.N. Thermal treatment of kaolin: Effect on the pozzolanic activity. Proc. Mater. Sci. 2012, 1, 343-350. [CrossRef]

43. Guo, Y.; Zhang, Y.; Soe, K.; Hutchinson, W.D.; Timmers, H.; Poblete, M.R. Effect of fly ash on mechanical properties of magnesium cement under water attack. Struct. Concr. 2019, 21, 1-19. [CrossRef]

44. Shi, E.; Wang, A.; Ling, Z. MIR, VNIR, NIR, and Raman spectra of magnesium chlorides with six hydration degrees: Implication for Mars and Europa. In Proceedings of the 50th Lunar and Planetary Science Conference, The Woodlands, TX, USA, 18-22 March 2019.

45. Brichni, A.; Hammi, H.; Aggoun, S.; Mnif, A. Optimisation of magnesium oxychloride cement properties by silica glass. Adv. Cem. Res. 2016, 28, 654-663. [CrossRef]

(C) 2020 by the authors. Licensee MDPI, Basel, Switzerland. This article is an open access article distributed under the terms and conditions of the Creative Commons Attribution (CC BY) license (http://creativecommons.org/licenses/by/4.0/). 